\title{
How to implement marketing strategies using database approaches
}

Received (in revised form): 22nd September, 2003

\section{Hoda McClymont}

is an associate lecturer at the University of Southern Queensland teaching in the fields of marketing research and consumer behaviour. She has worked in the private sector and for government agencies at local, state and federal levels. Her research interests include database marketing, health marketing and tourism.

\section{Graham Jocumsen}

is a senior lecturer in marketing at the University of Southern Queensland with extensive teaching, consulting and research experience in marketing strategy, marketing research, marketing management and small enterprise marketing. He held senior faculty management positions prior to 1990 before returning to mainstream academic pursuits.

\begin{abstract}
Available technology has been primarily responsible for the rapid expansion of use of database marketing by firms in Australia. This paper, using the literature and qualitative empirical data, has built and evaluated (using case study methodology) a conceptual framework for formally identifying and assessing the opportunities for using databases in implementing marketing strategies. It was found that databases could be used to implement marketing strategies associated with customer retention, customer reactivation, product/service-related and promotion-related marketing strategies. The way the database was used to implement these strategies and the extent of this usage depended, however, on factors such as the product type, channel intermediaries, firms' operations, firm size and the sophistication of the firms' marketing activities.
\end{abstract}

\section{INTRODUCTION}

The use of customer databases to pursue segmentation and targeting strategies has provided opportunities to significantly improve marketing effectiveness and to reduce marketing costs. ${ }^{1}$ Consequently, the adoption of database marketing by firms has increased rapidly in many industries ${ }^{2,3}$ for a number of reasons. ${ }^{4}$ For example, over 87 per cent of Australian firms now make varying uses of databases in implementing their marketing strategies. ${ }^{5}$ Direct marketing advertising expenditure (of which use of database approaches are a part) exceeded Aus $\$ 16.46$ bn in 2001. ${ }^{6}$ A business survey conducted in 2001 showed that close to
50 per cent of respondents planned to increase investment in database development and management in 2002 . $^{7}$ The rapid expansion of service offerings demanding close customer interaction has further stimulated adoption of database marketing approaches. ${ }^{8}$ Furthermore, many firms are now integrating database marketing with web-based tools and techniques, ${ }^{9}$ thus providing marketers with expanding opportunities to exploit both interactivity and personalisation associated with their marketing efforts.

Researchers have been challenged to keep pace with the widespread and rapid adoption of database marketing in practice, resulting in a relative paucity of 
guidance material published in scholarly marketing journals. Specifically, the literature lacks a conceptual framework which links marketing strategies to potential uses of database approaches. Hence, the aims of this paper are first to develop a conceptual framework which shows how marketing strategies may be implemented using database marketing approaches and secondly to explore the extent and reasons for such usage, using the literature and exploratory case study research.

Definitions of database marketing vary widely. ${ }^{10-14}$ For the purpose of this research, database marketing is defined as a system that relies on a variety of information technology tools and large volumes of historical and/or real-time, up-to-date, comprehensive data about customers, inquiries, prospects and suspects to assist in developing and implementing marketing strategies, with the ultimate aim of developing longstanding relationships of repeat business with customers (National Centre for Database Marketing's definition). ${ }^{15}$

\section{METHODOLOGY}

The methodology chosen for this research was exploratory and involved two stages. First, a comprehensive literature search embracing both database marketing and mainstream marketing was conducted to identify feasible marketing strategies which could utilise database marketing. The second stage involved case research which sought to investigate the extent of usage and reasons for such usage of database approaches in

Australian businesses in relation to the identified marketing strategies from the literature. The target population included all firms in Australia which practised database marketing. Absence of a list of such firms led the authors to develop a 'convenience' target list by asking several expert interviewees (three database marketing practitioners and two marketing consultants) to name Australian firms (in Brisbane, Sydney and Melbourne) known to engage in database marketing. Sufficient firms were then approached to obtain a total of 11 firms willing to participate in the research, a number deemed adequate for research of this nature. ${ }^{16-20}$

A total of 13 interviews were conducted with members of the 11 selected firms drawn from a range of industry types, channel types and head office locations (two interviews were conducted in three of the case firms). The cases were named after the industry in which they operated. The case list comprised consumer goods, fast food, publishing 1 , publishing 2 , automobile, financial 1 , financial 2 , telecommunication, charity, photography and art. In summary, the cases spanned a total of nine industries, comprising up to four types of channel intermediaries, offering goods or services as their primary product type and having head offices which were based either in Australia, the USA or Sweden.

Appropriate steps to maintain validity and reliability of this qualitative research were used. ${ }^{21}$ For example, triangulation of sources ${ }^{22}$ was achieved by collecting documents from the firms interviewed (to verify their assertions), conducting field observations and asking respondents to review an early draft of the interview transcripts in order to correct any inaccuracies and misconceptions. Content analysis of the interview transcripts permitted exploration of reasons for database marketing strategies. Further, reliability was achieved by using a case study interview protocol which provided a standard set of questions that was asked at each interview. The interview protocol opened with a broad question which asked respondents to provide the 'story 
Table 1: Marketing strategies which utilised database marketing, as cited in the literature

\begin{tabular}{|c|c|c|c|c|c|}
\hline Author & $\begin{array}{l}\text { Strategies } \\
\text { Customer } \\
\text { retention }\end{array}$ & $\begin{array}{l}\text { Customer } \\
\text { reactivation }\end{array}$ & $\begin{array}{l}\text { Product/ } \\
\text { service }\end{array}$ & $\begin{array}{l}\text { Promotion: } \\
\text { Prospecting }\end{array}$ & $\begin{array}{l}\text { Promotion: } \\
\text { Cross-selling }\end{array}$ \\
\hline $\begin{array}{l}\text { Caroll } \\
\text { Mitchell and Boustani }^{30} \\
\text { Reichheld and Aspinall }^{31} \\
\text { Berman }^{32} \\
\text { McEwan }^{33} \\
\text { Morrall }^{34} \\
\text { Keaveney }^{35} \\
\text { Marvin }^{36} \\
\text { Hughes }^{37} \\
\text { Finnegan }^{38} \\
\text { Reichheld }^{39} \\
\text { Campbell }^{40} \\
\text { Geller }^{41} \\
\text { Hall, Press, Ganey and Hall } \\
\text { Hepworth } \\
\text { Berry } \\
\text { Howe }^{45} \\
\text { Lynn }^{46} \\
\text { Oggenfuss }^{47} \\
\text { Oppermann } \\
\text { O'Malley }^{48} \\
\text { Crié } \\
\text { Kassing }^{51} \\
\text { Total }^{48}\end{array}$ & $\sqrt{ }$ & $\begin{array}{l}\sqrt{ } \\
V \\
\sqrt{ } \\
\\
\sqrt{ }\end{array}$ & $\begin{array}{l}\sqrt{ } \\
\sqrt{ }\end{array}$ & $\begin{array}{l}\downarrow \\
\downarrow \\
\downarrow\end{array}$ & $\begin{array}{l}\sqrt{ } \\
\sqrt{ }\end{array}$ \\
\hline
\end{tabular}

of their experiences' relating to implementing marketing through their databases. This question was followed by more specific ones targeted at each marketing strategy to determine the extent of usage of database approaches and underlying reasons for such usage.

\section{RESULTS: LITERATURE}

The literature revealed four major classes of marketing strategies that were pursued through the database: customer retention, customer reactivation, product/service and promotion strategies ${ }^{23-28}$ as shown in Table 1. The frequencies with which each database marketing strategy was cited are shown in Table 1. Customer retention and reactivation were most frequently cited. Each marketing strategy which utilised database marketing approaches as identified in the literature will now be addressed in turn.

\section{Customer retention}

Customer retention utilising database marketing is defined as building long-term business with customers through the gathering and storing of information on a database about customers' characteristics, their purchasing patterns and satisfaction levels with purchases. ${ }^{52}$ Customer retention directly influences a firm's profitability levels ${ }^{53}$ because it is more expensive to acquire a new customer than to retain an existing one. ${ }^{54}$ Furthermore, the longer a customer remains with a firm, the more likely it is that the organisation could increase its share of the customer's expenditure and hence further contribute to profitability. ${ }^{55}$ Nevertheless, many firms still spend a significant amount of their marketing budgets on customer acquisition at the expense of customer retention. ${ }^{56}$

Current marketing literature emphasises that customer retention 
Table 2: Ansoff's product/service-market matrix and marketing strategies which may utilise database approaches

\begin{tabular}{lll}
\hline & Existing market & New market \\
\hline Existing product(s)/service(s) & $\begin{array}{l}\text { Promotional strategies utilising database marketing } \\
\text { Market penetration } \\
\text { Cross-selling (selling on, selling across, } \\
\text { up-selling and down-selling) }\end{array}$ & $\begin{array}{l}\text { Market development } \\
\text { Prospecting }\end{array}$ \\
& $\begin{array}{l}\text { Product/service development strategies utilising database marketing } \\
\text { Diversification }\end{array}$ \\
New/modified product(s)/ & $\begin{array}{l}\text { Product/service development } \\
\text { New/modified product/service } \\
\text { development-current customers }\end{array}$ & $\begin{array}{l}\text { New/modified } \\
\text { product/service } \\
\text { development-prospective } \\
\end{array}$ \\
& & customers \\
\hline
\end{tabular}

'Includes 'repeat selling'

${ }^{b}$ Assumed here that 'new' includes significant product/service modification (innovations, new brands, improvements)

includes two processes: the identification of tactics to be used to retain customers $^{57-59}$ and the identification of criteria for determining the 'right' customers to be selected for retention. ${ }^{60}$ Extending the Pareto principle, the 'right' customers are the 20 per cent of loyal, highly profitable customers who generate 80 per cent of a firm's profits. ${ }^{61}$ Suggested tactics for customer retention from the literature include customising products and services according to customers' needs ${ }^{62,63}$ maintaining customer contact ${ }^{64,65}$ and developing customer loyalty programmes. ${ }^{66}$

\section{Customer reactivation}

While retention and reactivation are closely related, specific reactivation strategies may become appropriate where loyal customers defect despite every best effort in implementing retention strategies. The existing literature on customer defection focuses on the reasons why customers defect, ${ }^{67-69}$ the ways in which customers could be reactivated (for example, through employee training and surveys) $)^{70,71}$ and ways to stop customers from lapsing in the first place. ${ }^{72,73}$ For example, reactivating lapsed customers requires identifying which customers have defected, researching and analysing the reasons why they left and finally using this information to reactivate them where possible. $^{74}$

\section{Product/service and promotional strategies}

Two key themes on use of database marketing in implementing product/service and promotional strategies emerged from the database and marketing literature. First, in keeping with the marketing concept philosophy, ${ }^{75}$ databases were seen to contribute to overall product/service development ${ }^{76,77}$ by providing information to monitor and assess changing customer needs and wants. Secondly, databases contribute to promotional strategies ${ }^{78,79}$ through crossselling (offering current customers related or unrelated products) ${ }^{80-83}$ and prospecting (selling existing products to prospective buyers). ${ }^{84-86}$

Developing Drozdenko and Drake further, ${ }^{87}$ in order to embrace all themes which emerged from the database marketing literature in relation to promotional and product/service strategies specifically, these strategies were categorised using Ansoff's product-market 
Table 3: Conceptual framework

\begin{tabular}{lll}
\hline Strategy class & Strategy subclass & Customer class \\
\hline 1 Customer retention & & Current \\
2 Customer reactivation & New product/service development & Lapsed \\
3 Product/service related & Current \\
& Modified product/service development & Prospective \\
& Current \\
4 Promotion related & Prospecting & Prospective \\
& & Current \\
& & New \\
\hline
\end{tabular}

matrix. ${ }^{88}$ The top two quadrants (Table $2)^{89}$ were used to categorise promotional strategies into cross-selling (Ansoff's market penetration) and prospecting (Ansoff's market development), while the bottom two quadrants were used to categorise product/service strategies into new/modified product/service development (current customers Ansoff's product/service development) and new/modified product/service development (prospective customers Ansoff's diversification).

In summary, Table 3 represents a conceptual framework for marketing strategies which utilised database marketing approaches as identified in the literature.

\section{RESULTS: CASE STUDIES}

Qualitative data collected focused upon both the extent of usage and rationale for using database marketing in pursuing the marketing strategies depicted in the conceptual framework (Table 3). While all such marketing strategies were cited by respondents, the most frequently cited ones for which database marketing approaches were used were customer retention, customer reactivation, cross-selling (promotion strategy), new product/service development and product/service modification for current customers (product strategy). The least frequently cited marketing strategies for which database marketing approaches were used included new product/service development and product/service modification for prospective customers and prospecting as a promotional strategy. Each strategy will now be addressed in the order in which they appeared in the conceptual framework (Table 3).

\section{Customer retention}

Data analysis revealed three ways in which the case firms used database approaches in implementing a customer retention strategy (row (a) of Table 4). First, some firms sought to retain customers by rewarding them on an ongoing basis (passive retention). The three firms that did this were automobile, consumer good and charity. Charity utilised quarterly newsletters to its customers, automobile sent free golf tournament tickets to those of its customers who noted that they were interested in golf and consumer goods 2 sent invitations to some of its customers for fashion parades and shopping nights.

Secondly, several firms identified potential defectors based upon triggers that managers identified through judgment and knowledge (active retention). The three firms falling into this category were publishing 2, fast food and telecommunication. For example, publishing 2 offered free gifts as encouragement to renew magazine subscriptions before expiry. Similarly, fast food's management sought feedback from 
Table 4: Extent of database usage in marketing strategy development and reasons for non-usage

\begin{tabular}{|c|c|c|}
\hline Strategy (i) & Extent of usage (ii) & Reason for not using database (iii) \\
\hline (a) Retention & $\begin{array}{l}\text { Database not used at all } \\
\text { Passive retention } \\
\text { Active retention } \\
\text { Reactivation }\end{array}$ & $\begin{array}{l}\text { Firm had not thought of the idea } \\
\text { Head office overseas } \\
\text { Not profitable } \\
\text { Internal skills lacking }\end{array}$ \\
\hline (b) Reactivation & $\begin{array}{l}\text { Database not used at all } \\
\text { Research } \\
\text { Testing } \\
\text { Ineffective }\end{array}$ & $\begin{array}{l}\text { Lack of resources } \\
\text { Not profitable } \\
\text { Internal skills lacking } \\
\text { Firm had not thought of the idea }\end{array}$ \\
\hline $\begin{array}{l}\text { (c) New product } \\
\text { development/product/ } \\
\text { service modifications } \\
\text { for customers }\end{array}$ & $\begin{array}{l}\text { Database not used at all } \\
\text { Idea generation } \\
\text { Research } \\
\text { Testing } \\
\text { Combination }\end{array}$ & $\begin{array}{l}\text { Database consists of donors not customers } \\
\text { New product development is not a usual } \\
\text { occurrence } \\
\text { Firm is a wholesaler not manufacturer } \\
\text { (Australian) customer database is not large } \\
\text { enough } \\
\text { Database not required for walk-in orders } \\
\text { Modifications are market-driven rather than } \\
\text { customer-driven } \\
\text { Firm had not thought of the idea } \\
\text { Customer input not vital }\end{array}$ \\
\hline $\begin{array}{l}\text { (d) New product } \\
\text { development/product/ } \\
\text { service modifications } \\
\text { for prospects }\end{array}$ & Database not used at all & $\begin{array}{l}\text { Number of prospects on the database is not } \\
\text { high enough and therefore not profitable } \\
\text { enough } \\
\text { Database not required for walk-in orders } \\
\text { (Australian) customer database is not large } \\
\text { enough } \\
\text { Firm had not thought of the idea }\end{array}$ \\
\hline (e) Prospecting & $\begin{array}{l}\text { Direct marketing method } \\
\text { Database marketing method }\end{array}$ & $\begin{array}{l}\text { Firm did not think that prospecting could be } \\
\text { undertaken with the database } \\
\text { Firm had not thought of the idea }\end{array}$ \\
\hline (f) Cross-selling & Implemented widely & $\begin{array}{l}\text { All database customers are included in } \\
\text { campaign so there is no need for a } \\
\text { database to segment the customer base } \\
\text { Firm had not thought about using the } \\
\text { database for this strategy } \\
\text { Irrelevant for product type } \\
\text { Sophisticated modelling requirements not } \\
\text { available to firm } \\
\text { Firm had not thought of the idea }\end{array}$ \\
\hline
\end{tabular}

customers who had ordered little recently. Finally, telecommunication examined attrition trends in its database to identify potential defectors, consequently contacting them better to understand and serve their needs.

Thirdly, some firms sought to identify and retain possible defectors by using sophisticated mathematical models rather than relying upon managerial judgment and knowledge (scientific retention). For example, financial 1 modelled its database to build an 'attrition score' that identified potential customer defectors and their characteristics that might trigger defection. Similarly, publishing 1 modelled its database to identify possible defectors (customers who had not purchased for a specified time period). Financial 1 and publishing 1 , both amply resourced, were highly experienced with the use of database marketing approaches and hence exhibited sophisticated construction, management and use of the database. 
Only one firm, financial 2, did not implement a customer retention strategy using the database but rather simply observed customers during interactions for potential defection behaviours such as seeking payout figures for loans. This firm, lacking skills and knowledge of database approaches relied on traditional means to monitor customer behaviour. Another firm, art, did not implement a retention strategy, with or without the use of a database, because such strategy was decided and implemented by head office overseas. The firm's head office, however, did identify and communicate directly with 'at risk' customers in Australia.

\section{Customer reactivation}

Customer reactivation as a marketing strategy seeks to win back buying support from former customers who had ceased buying from a firm. ${ }^{90}$ Results for the analysis of the six cases which implemented this strategy through the database showed three approaches towards reactivation (as shown in row (b) of Table 4); research, testing and ineffective. First, some firms (telecommunication, fast food and publishing 2) identified lapsed customers and their purchasing characteristics before conducting attitudinal research to investigate the factors which caused attrition. Information gained through this process was used to develop reactivating offers. This approach to customer reactivation was termed 'research'.

Secondly, one firm (consumer goods) identified its lapsed customers and designed offers geared specifically towards reactivation, but tested these reactivation offers prior to launch. That is, consumer goods did not research customers before developing its offers to reactivate but rather tried strategies out through a trial and error-based 'testing' process.
Thirdly, two firms (publishing 1 and art) pursued a selling strategy rather than a reactivation strategy. Here, lapsed customers for a product line/item were simply identified and excluded from future promotional offers with no steps taken to find out why customers lapsed and how they might be reactivated. For example, publishing 1 identified lapsed customers and simply excluded them from future promotional campaigns because they 'were not profitable'. Similarly, art mailed various offers from its different product lines to a customer over a period of time, recording responses and excluding those not responding over a two-year period. This approach is termed 'ineffective' because of its lack of focus on customer behaviour patterns which may provide clues to underlying causes of defection or lapsing.

One firm (charity) pursued a reactivation strategy but without database use because of a lack of funds and sensitivities of donors to amounts of money spent on administration. Its reactivation strategy simply consisted of following up on customers indicating they were ceasing donations. While a further firm (automobile) did not have a reactivation strategy (although it felt that it 'should') it nevertheless used mathematical tools to determine probabilities of purchase by customer groups. The relevance of defection in automobiles is lower than for consumer goods because of the relative infrequency of repeat purchases in the former.

\section{Product/service-related strategies: New product/service development and product/service modification for current customers}

Numerous firms used the database to implement marketing strategies involving new or modified products/services because the customer was perceived to 
be an important contributor to the entire process of new product/service development and product/service modification (telecommunications). In all cases, the customer database was used either for new/modified product/service idea generation, research, testing or for a combination of these activities (fast food; photography; financial 1; financial 2; telecommunication; publishing 1 ; consumer goods) (row (c) of Table 4). For example, telecommunication used the database to generate new product/service ideas (stored in its database from past customer feedback and comments) prior to researching its customers to refine the new product/service idea.

Further, the database was used initially to research the new product/service idea (publishing 1, financial 1 and 2, telecommunication and consumer goods). For example, publishing 1 formally sought customer responses (negative and positive) through questionnaires when screening new book ideas for potential 'winners'. Also, telecommunications used the database to identify manageable groups of consumers in order better to deliver genuine value through its complete communication line of products and services. Similarly, one firm pursued a product/service modification strategy when it was found that a product/service was not selling well. The database was used to determine current and lapsed users of the product/service and to identify possible new markets for variations of the product or service (publishing 2). This was seen as market expansion through product/service modification. Two firms used database research to determine the aspects of a product/service offering which might need modification to suit customer needs better (publishing 1 and publishing 2).

Fast food and photography used the database for new/modified product/service idea testing. These firms tested the new/modified product/service idea by selling a prototype to database customers and using behavioural responses to predict success. Other firms used the database to help identify and research the specific customer segments they sought to target when

contemplating new product/service development. These customer segments were usually the most profitable ones as indicated through analysis of the database (telecommunications, consumer goods, financial 1 and financial 2).

One firm pursued a product/service modification strategy when it was found that a product/service was not selling well. The database was used to determine current and lapsed users of the product/service and to identify possible new markets for variations of the product or service (publishing 2). This was seen as market expansion through product/service modification. Two firms used database research to determine the aspects of a product/service offering which may need modification to suit customer needs better (publishing 1 and publishing 2).

On the other hand, automobile had the capacity to modify products/services for its current customers through the provision of 'extras', without reference to a database. In a similar vein, another firm's head office overseas assumed responsibility for new product/service development, assuming the Australian market would simply ride on overseas successes (art). Retailing firms such as consumer goods could adjust their product/service portfolios but could not modify products/services per se. In instances where falling sales were caused by market-related factors such as price and supply rather than customer behaviour factors, a product/service modification strategy became less appropriate. For example, one firm 
discovered that falling sales were due to more successful competing products/services in the market rather than particular deficiencies in its own current offerings (financial 2). New product/service development was rare in the case of one firm which produced only one major product line, comprising three magazines (publishing 2).

Only one firm, charity, stated that it developed new products/services without the database because of the nature of the database itself. Charity could not use its customer database to develop new products/services (cures for disease in this instance) because its database consisted of donors towards the new product/service research as distinct from the beneficiary recipients (patients) of the new product/service cures. Decisions about which new areas to research for cures were made by the firm in response to those diseases that were currently of importance to the community rather than what the database donors wanted. The database in this instance was used merely for obtaining donations.

\section{Product/service-related strategies: New product/service development and product/service modification for prospects}

One firm only (telecommunications) implemented this strategy through the database. The remainder did not implement this strategy through the database because the database either did not contain prospects or contained too few to warrant new product/service development (row (d), Table 4). Furthermore, only one firm, fast food, modified products/services for prospects without the database because the product/service modification strategy was irrelevant to database marketing. 'If someone wants pizza with different toppings/herbs then fast food will do it for them' (fast food). While the case firms in this study exhibited little use of database approaches in implementing a diversification strategy, nevertheless databases of potential customers could be developed or purchased by firms seeking to pursue new customers with new or modified products/services. ${ }^{91}$

\section{Promotion-related strategies: cross-selling}

Cross-selling (encompassing selling on, selling across, up-selling, down-selling and repeat selling) was implemented widely by the case firms using database approaches. Database information was used to assess profitability of various customer segments and to gain a more complete description of the customers and their potential buying behaviours. For example, one respondent (telecommunications) commented: 'Through segmentation using the database, we identify and target the most profitable customers and customise our product/service and communications based on what we know about them.' This firm also stressed the importance of use of the database to help build relationships and long-term profitability. 'If customers are sold more than one type of product then our ability to retain them significantly increases'

(telecommunications). The database was seen as a means to maximise profits by selling more product to existing customers, that is, targeting the most profitable customers with multiple product offerings. Furthermore, the database permitted ready identification of customers deemed to be 'prospects' for certain products. For example, financial 2 used product/service type, age of customer, bank balances and types of accounts to determine the type of product/service to cross-sell to its current 
customers. In contrast, however, cross-selling was essentially precluded as a feasible strategy in those cases where initial purchase was a 'one off' such as for cars (automobile), books (publishing 1) and artworks (art). In such cases, firms merely 'maintained contact' to gain preferential consideration in future purchase situations.

Results showed that cross-selling could be classified into three approaches - the trial and error approach, the managerial approach and the scientific approach (row (e), Table 4). First, some firms investigated customer needs through trial and error (art, publishing 2 and financial $2)$. For example, art explained that it sought true customer motivations to purchase works of art by seeking responses to a range of different direct mail offerings after an initial purchase had been made. This way, art could determine, by trial and error, if the customer was motivated by, for example, the designer, the design itself, the object of the design or by collection per se and hence maximise opportunities to cross-sell successfully. Further, the use of subscriber inserts in magazines

represented another example of the trial and error approach in cross-selling. Here, attempts were made to cross-sell magazines across customer groups. Lack of response resulted in cessation of such activity for a period of time (publishing 2). The non-relational nature of publishing 2's database precluded sophisticated segmentation.

Finally, financial 2 typically used one or two variables on a two-dimensional table to segment customers for cross-selling. For example, for cash management products/services, the firm used age and balance range to segment customers. This firm, however, also used statistical analysis where necessary to segment customers using multiple variables (financial 2).
Secondly, the managerial process of cross-selling involved management making judgments about the most appropriate segments to cross-sell to, based on past experience. For example, fast food segmented the database by total spend levels for its various geographic regions to identify the 'most profitable regions to sell to' (fast food).

Finally, with the scientific method, the firm relied upon mathematical modelling of historical information about customers captured in the database in order to select customer segments that appeared more receptive to cross-selling efforts than others (publishing 1). The models allowed the firm to identify characteristics associated with customers who bought certain products that were similar or related to the product that was to be used in cross-selling. For example, publishing 1 modelled the database using many behavioural variables including RFM (recency, frequency and monetary values), how many times the customer had bought/not bought a product, whether or not the customer had paid for the good, and the type of products bought and their prices.

\section{Promotion-related strategies: Prospecting}

Prospecting was not carried out through the database by most firms because they felt that obtaining a list or including direct advertising in magazines were the only available ways that could be used for prospecting (row (f), Table 4). There was clearly a degree of ignorance among the case firms about the potential for contacting prospective customers using the database.

Of the eight firms who responded to this question, six firms prospected without the database and only two firms used the database to prospect. Firms who prospected without the database decided 
on segments of consumers to target for prospecting before initiating contact.

Firms then either bought relevant lists to direct mail to those segments or advertised through mailbox drops or through magazines read by those segments. These prospecting approaches were in the form of competitions and free gifts to entice prospects to send in their personal details. Any prospective customers responding to these direct mailings were entered onto the database and were then treated as current customers. For example, publishing 2 inserted coupons for free presents in magazines read by consumer segments targeted for prospecting. The aim was to obtain customers' personal details for future mailings. Therefore, the process of prospecting in these instances did not require use of a database in the first instance.

The remaining two firms used their databases to select relevant customer segments to prospect to but used dissimilar approaches. The first firm, publishing 1 , used behavioural data to identify its most profitable customers. Next, it added geodemographic data to profile these profitable customers and identify the suburbs/cities where they resided. Finally, it selected those identified suburbs/cities for its direct mail prospecting campaign. This was based upon the logic that regions containing a firm's best customers became the best ones for prospecting because they contained other consumers with similar characteristics. Therefore, the more similar these customers were to the firm's best customers, the more likely it was that they would also be interested in the firm's products. Publishing 1, however, noted that although this method of prospecting was the most objective method, it was not very effective because of the limiting underlying assumption that all potential customers in an entire region had similar characteristics to three or four individual customers residing in that region.

The second firm, charity, used its hospital's database to select all adult patients for prospecting. The hospital's database was used because it was assumed that patients were more sympathetic to donating towards research for cures for diseases than non-patients. Furthermore, adults were selected because they had the financial means to make donations.

Prospecting was implemented through the database for two main reasons. First, the database was used because potential customers' names could be obtained from other service sectors of a firm's parent organisation. For example, patients in a hospital were willing to contribute to a charity's research efforts because such efforts ultimately affected their personal wellbeing (charity). Secondly, a database was used because database prospecting using geodemographic segmentation may be the most effective way to prospect where other more scientific methods do not currently exist. Use of a database to prospect for new customers rested, however, on the existence of a suitable database for the purpose. In many instances such a database did not exist for a firm and it was forced to use non-specific promotions such as coupons, vouchers and advertisements to obtain new customers (publishing 1 and charity). Of course, once a prospect became a customer they then entered the database and hence were available to use in marketing strategy implementation (publishing 2).

\section{CONCLUSIONS}

While the case studies demonstrated that different firms may place different emphases upon the various ways in which databases can be used to implement marketing strategies, they 
nonetheless have shown that the conceptual framework of Table 3 embraces the marketing strategies which may be implemented through database approaches. Examples of database use for all marketing strategies contained in the conceptual framework (Table 3) were cited by at least one respondent from the case firms. This research found that certain combinations of marketing strategy and database approach occurred more frequently in practice than others. Factors such as nature of the industry (products and services), characteristics of buyer behaviours, technological sophistication within the firm, size of the firm, satisfaction with current non-database approaches and availability of database data contribute to variations in database usage in marketing strategy implementation. For example, product modification for current customers was not a popular database marketing strategy for most firms because products can be modified (customised) for customers during the order and purchase process without the need to use a database.

In brief, this research has developed a conceptual framework which embraces the range of marketing strategies which may be implemented with database approaches and has shown, through examination of 11 case businesses, that such a framework is a valid one for identifying opportunities for using database marketing in marketing strategy implementation in practice. It is suggested here that firms, when choosing and implementing marketing strategies, canvass the potential ways in which database marketing approaches may be fully integrated into marketing planning processes. $^{92}$ For example, choice of marketing strategies themselves may be influenced by the potential to utilise databases in various ways. Further research, using quantitative methodologies, will be necessary to confirm the findings of this study and possibly to refine the conceptual framework developed. In addition, future research will be needed to explore how the internet may be fully integrated with database approaches to implement selected marketing strategies.

\section{References}

1 Paltschik, M. and Storbacka, K. (1992) 'Monitoring the customer base to achieve profitability', Marketing and Research Today, August, pp. $155-165$.

2 DeTienne, K. B. and Thompson, J. A. (1996) 'Database marketing and organizational learning theory: Towards a research agenda', Journal of Consumer Marketing, Vol. 13, No. 5, pp. 12-34.

3 Palmquist, J. and Ketola, L. (1999) 'Turning data into knowledge', Marketing Research, [CD-ROM], Vol. 11, No. 1, available: Business Source Elite.

4 Drozdenko, R. G. and Drake, P. D. (2002) 'Optimal database marketing', Journal of Marketing Research, Vol. 39, No. 4, pp. 499-501.

5 Styles, C. and Uncles, M. (1998) 'Marketing management in Australia — joint MI/UNSW survey', Professional Marketing, February/March, pp. 32-33.

6 Australasian Business Intelligence (2002) 'Direct marketing in a changed world', B \& T Weekly, [CD-ROM], 3rd December, available: ABIX via Comtex, scheme from: http://comtexnews.com.

7 Drozdenko and Drake (2002) op. cit.

$8 \quad$ Ibid.

9 Lane, M. S. and Cavaye, A. L. M (2000) 'Integrating web and database marketing: Australian study of direct marketing firms', Journal of Research and Practice in Information Technology, Vol. 32, No. 3-4, pp. 168-180.

10 Berman, K. (1994) 'Database marketing: A new secret weapon', Folio: The Magazine for Magazine Management, Vol. 22, No. 19, pp. 185-187.

11 Jutkins, R. (1994) 'Power direct marketing: How to make it work for you', NTC Business Books, Lincolnwood, USA.

12 Stanton, W. J., Miller, K. E. and Layton, R. A. (1994) 'Fundamentals of marketing', 3rd edn, McGraw-Hill Book Company, Sydney.

13 Li. S., Kinman, R., Duan, Y. and Edwards, J. S. (2000) 'Computer-based support for marketing strategy', European Journal of Marketing, Vol. 34, No. 5-6, pp. 551-575.

14 Bhattacharyya, S. (1999) 'Direct marketing performance modelling using genetic algorithms', Journal of Computing, Summer, Vol. 11, No. 3, pp. 248-257.

15 Hughes, A. M. (1996) 'The complete database marketer: Second-generation strategies and techniques for tapping the poser of your customer database', Irwin Professional Publication, Chicago. 
16 Perry, C. (1994) 'A structured approach to presenting PhDs: notes for candidates and their supervisors', ANZ Doctoral Consortium, University of Sydney, 4th-6th February.

17 Miles, M. B. and Huberman, A. M. (1994) 'Qualitative data analysis: An expanded sourcebook', 2nd edn, Sage Publications, Thousand Oaks.

18 Eisenhardt, K. M. (1989) 'Building theories from case study research', Academy of Management Review, Vol. 14, No. 4, pp. 532-550.

19 Romano, C. A. (1989) 'Research strategies for small business: A case study', International Small Business Journal, Vol. 7, No. 4, pp. 35-43.

20 Hedges, A. (1985) 'Group interviewing', in Walker, R. (ed.) 'Applied qualitative research', Gower, Aldershot.

21 Healy, M. and Perry, C. (2000) 'Comprehensive criteria to judge validity and reliability of qualitative research within the realism paradigm', Qualitative Market Research - An International Journal, Iss. 3, pp. 14-31.

22 Patton, M. Q. (1990) 'Qualitative evaluation and research methods', 2nd edn, Sage Publications, Newbury Park, USA.

23 Mitchell, V. M. and Boustani, P. (1993) 'Market development using new products and new customers: A role for perceived risk', European Journal of Marketing, Vol. 27, No. 2, pp. 17-32.

24 Morrall, K. (1994) 'Strategies to retain business customers', Bank Marketing, Vol. 26, No. 8, pp. 64-69.

25 McEwan, D. (1994) 'Growing your business with database marketing', Longman Australia Pty Ltd, Hong Kong.

26 Lynn, T. (1998) 'The customer lifecycle and how it influences your success', Rough Notes, [CD-ROM], Vol. 141, Iss. 5, pp. 78-79, available: Ebscohost Full Display.

27 Oppermann, M. (1999) 'Database marketing by travel agents', Journal of Travel Research, Vol. 37, No. 3, pp. 231-247.

28 Crié, D. (2002) 'When should a customer be defined as "lapsed"?', Interactive Marketing, Vol. 3, No. 4, pp. 324-336.

29 Carrol, P. (1991) 'The fallacy of customer retention', Journal of Bank Marketing, Vol. 13, No. 4, pp. 15-20.

30 Mitchell and Boustani (1993) op. cit.

31 Reichheld, F. F. and Aspinall, K. (1993) 'Building high-loyalty business systems', Journal of Retail Banking, Vol. 15, No. 4, pp. 21-29.

32 Berman (1994) op. cit.

33 McEwan (1994) op. cit.

34 Morrall (1994) op. cit.

35 Keaveney, S. M. (1995) 'Customer switching behaviour in service industries: An exploratory study', Journal of Marketing, April, Iss. 59, pp. 71-78.

36 Marvin, J. D. (1995) 'Keep movers from moving on', Bank Marketing, Vol. 27, No. 9, pp. 75-79.

37 Hughes (1996) op. cit.
38 Finnegan, D. E. (1996) 'Client prospecting using database technology and research', Trusts $\mathcal{E}$ Estates, Vol. 135, No. 12, pp. 43-44.

39 Reichheld, F. F. (1996) 'Learning from customer defections', Harvard Business Review, Vol. 74, No. 2, pp. 56-57.

40 Campbell, L. (1997) 'Orange sets up loyalty scheme', Marketing, November, p. 6.

41 Geller, L. (1997) 'Thank you so much for your recent purchase...customer begins with the basics', Direct Marketing, Vol. 60, No. 5, pp. $58-62$.

42 Hall, M. F., Press, I., Ganey, R. and Hall, D. (1997) 'Hello, I must be going', Bank Marketing, Vol. 29, No. 4, pp. 30-35.

43 Hepworth, M. (1998) 'The power of negative thinking', CMA - The Management Accounting Magazine, Vol. 72, No. 1, p. 34

44 Berry, M. (1998) 'The new integrated direct marketing', Brookfield VT, Gower, Hampshire.

45 Howe, D. (1998) 'The cross-sell connection', Banking Strategies, Vol. 74, No. 6, pp. 120-125.

46 Lynn (1998) op. cit.

47 Oggenfuss, C. W. (1998) 'Ratcheting-up retention’, Bank Marketing, Vol. 30, No. 5, pp. $28-37$.

48 Oppermann (1999) op. cit.

49 O’Malley, L. (1998) 'Can loyalty schemes really build loyalty', Marketing Intelligence \& Planning, Vol. 16, No. 1, pp. 10-15.

50 Crié (2002) op. cit.

51 Kassing, J. (2002) 'Increasing customer retention: Profitability isn't a spectator sport; it takes work and a good database', Financial Services Marketing, Mar-Apr, pp. 32-37.

52 Geller (1997) op. cit.

53 Coviello, N., Milley, R. and Marcolin, B. (2001) 'Understanding IT-enabled interactivity in contemporary marketing', Journal of Interactive Marketing, Vol. 15, No. 4, pp. 18-35.

54 Davenport, T. H., Harris, J. G. and Kohli, A. K. (2001) 'How do they know their customers so well?', Sloan Management Review, Vol. 42, No. 12, pp. 63-76.

55 Reichheld (1996) op. cit.

56 Bowman, S. (1996) 'Database technology eases prospecting chores', National Underwriter - Life and Health, Financial Services Edition, Vol. 1, No. 27, p. 19.

57 Geller (1997) op. cit.

58 Oggenfuss (1998) op. cit.

59 Hansen, L. (1998) 'Keep the customer satisfied', Marketing Tools, Vol. 5, No. 5, pp. 44-49.

60 Geller (1997) op. cit.

61 Hallberg, G. (1995) 'All consumers are not created equal', John Wiley \& Sons Inc, Brisbane.

62 Geller (1997) op. cit.

63 Gerson, V. (1998) 'Creating the prospect-driven company', American Salesman, Vol. 43, No. 8, pp. 3-10.

64 Hansen (1998) op. cit.

65 Furlong, C. B. (1993) '12 rules for customer 
retention', Bank Marketing, Vol. 25, No. 1, pp. $14-18$.

66 Hansen (1998) op. cit.

67 Oppermann (1999) op. cit.

68 Keaveney (1995) op. cit.

69 Marvin (1995) op. cit.

70 Lynn (1998) op. cit.

71 Campbell (1997) op. cit.

72 Reichheld (1996) op. cit.

73 Advertising Age (1998) 'Building brand loyalty', Advertising Age, Vol. 83, No. 5, pp. S1-3.

74 Reichheld, F. F. and Sasser, W. E. (1990) 'Zero defections: Quality comes to services', Harvard Business Review, Vol. 68, No. 5, pp. 105-111.

75 Kotler, P. (2003) 'Marketing management: International edition', 11th edn, Pearson Education Inc., Australia.

76 Davenport et al. (2001) op. cit.

77 Master, H. (2000) 'Database marketing segmentation for strategy development in Australian industries', PhD thesis, The University of Southern Queensland, Toowoomba, Australia.

78 Schoenbachler, D. D., Gordon, G. L., Foley, D. and Spellman, I. (1997) 'Understanding consumer database marketing', Journal of Consumer Marketing, Vol. 14, No. 1, pp. 5-19.
79 Gunaratne, K. A. (1998) 'Database marketing a dream comes true', in 'Proceedings of Australia New Zealand Marketing Academic Conference', Otago New Zealand, December.

80 Oppermann (1999) op. cit.

81 Kassing (2002) op. cit.

82 Kim, B. and Kim, S. (1999) 'Measuring upselling potential of life insurance customers: Application of stochastic frontier model', Journal of Interactive Marketing, Vol. 13, No. 4, pp. 2-9.

83 Knott, A., Hayes, A. and Neslin, S. A. (2002) 'Next-product-to-buy for cross-selling applications', Journal of Interactive Marketing, Vol. 16, No. 3, pp. 59-75.

84 Drozdenko and Drake (2002) op. cit.

85 Howe (1998) op. cit.

86 O'Malley (1998) op. cit.

87 Drozdenko and Drake (2002) op. cit.

88 Ansoff, I. (1957) 'Strategies for diversification', Harvard Business Review, September-October, Iss. 114.

89 Source: Based on Ansoff's product/service-market matrix in Mitchell and Boustani (1993) op. cit.

90 Reichheld and Sasser (1990) op. cit.

91 Drozdenko and Drake (2002) op. cit. 92 Ibid. 